ORIGINAL ARTICLE

\title{
The Relationshıp Between Injury Anxiety and Forgiveness Flexıbility: A Research for Elite Field Hockey Athletes
}

\author{
KÜRŞAD HAZAR ${ }^{1}$ \\ Osmaniye Korkut Ata University, kursathazar@hotmail.com- ORCiD:0000-0002-6159-2631
}

\begin{abstract}
Purpose: This study aims to examine the relationship between injury anxiety and forgiveness flexibility levels of elite field hockey players. Injury anxiety and forgiveness flexibility levels were compared in terms of gender, the status of being a national athlete, injury history, and frequency of training.

Method: In line with the purpose of the research, it is descriptive research in which the relational survey model, one of the quantitative research methods, is used. With this method, it is used to grasp and explain the relationship between various variables without any attempt to change the current situation. In this framework, a research model was created that aims to determine the existence of covariance between two or more variables. The research population consists of field hockey players. The population of the study is elite field hockey players who participated in national or international field hockey tournaments. The research sample consists of 161 participants (66 Female, 41\%; 95\% Male, 59\%) selected by convenience sampling method, which is one of the non-random sampling methods. The "Sports Injury Anxiety" scale was used to determine the injury anxiety levels of field hockey players who participated in the study voluntarily. The "Forgiveness Flexibility Scale" was used to determine the levels of forgiveness flexibility, and the "Personal Information Form" prepared by the researchers was used to collect information about demographic characteristics (gender, status of being a national athlete, injury history, training frequency).

Conclusion: It was determined that there was a significant difference in injury anxiety and forgiveness flexibility scores of elite field hockey players according to gender and training frequency variables. On the other hand, while there was a significant difference in injury anxiety scores according to the status of being a national athlete and having an injury, no significant difference was found in the mean scores of forgiveness flexibility. As a result of the analysis performed to determine the relationship between injury anxiety and forgiveness flexibility, a positive and significant relationship was determined between the injury anxiety and forgiveness flexibility levels of the athletes. Finally, it was concluded that training frequency is an important predictor of injury anxiety, and as the training frequency increases, the athlete's injury anxiety level decreases.

Keywords: Field hockey, injury anxiety, forgiveness flexibility
\end{abstract}

\section{INTRODUCTION}

Doing sports and taking part in sports activities can contribute to both the psychological and physical development of the individual. While it contributes to physical development, it may also contain some risk factors. One of these risk factors is sports injuries. Sports injuries are defined as loss of function that occurs during activity. ${ }^{1}$ Sports injuries can result in worrisome situations in individuals. Such situations that affect sports performance can be determined and controlled. Anxiety can also occur as another factor affecting sports injuries. It has been demonstrated by some studies that high anxiety level is a condition that affects athlete injuries. ${ }^{2}$

While athletes' injuries cause a decrease in the physical capacity of individuals, it can also cause psychological consequences such as not regaining their former form and losing their status. Even if the physical condition of the athletes after the injury is restored, the emotional state of the individual may be affected. ${ }^{3}$ At this point, psychological dynamics are important for the individual to regain his former form. Eliminating the athlete's injury anxiety or keeping the anxiety at an optimal level can increase the performance of the individual. One of the important factors for success is to identify and prevent situations that trigger stress.

Forgiveness of the individual after sports injuries may provide a decrease in his emotional disorder. The ability of the athlete's forgiveness flexibility may affect the athlete's return to pre-injury performance. Forgiveness is expressed as nurturing compassion by approaching the person who hurt him with positive emotions. ${ }^{4}$ Because a long-lasting emotional disorder can cause an increase in the level of anger and depression in the individual. Reducing stressrelated components in maintaining a physically healthy state may be associated with forgiveness. In addition, forgiveness can be shown as fair play behavior for all athletes. Parallel to this thought, it is stated that to prevent injuries, the concern about whether the injured athletes will be able to regain their previous performance despite being well trained. ${ }^{24}$ Long-term injury and disability can also cause low self-confidence in the athlete. ${ }^{26}$

Forgiveness appears as a moral reaction as a result of an unjust behavior by the opponent.5 The concept of flexibility can be expressed as the individual choosing the appropriate one in the face of more than one option. For athletes, a high level of flexibility can offer the key to success. ${ }^{6}$ Forgiveness flexibility can be expressed as the ability to minimize the destructive effect of the encountered event. In addition, the flexibility of forgiveness can provide guidance to the individual in terms of forgiving behavior. Individuals with high forgiveness flexibility can quickly overcome their stressful emotional state in the face of positive emotional states and negative situations and injuries they encounter. ${ }^{7}$ This situation can turn into an advantage and contribute to the individual. Another point to be noted here is that forgiveness does not mean ignoring the situation or acting as if it did not happen. Forgiveness 
has an aspect that reflects on individuals' behaviors and views of life (Ayten, 2009). It can also be said that the individual tends towards the positive by forgiving. Forgiveness flexibility and forgiveness can make positive contributions in both individual and team sports. This contribution can contribute not only to the forgiven but also to the person who performs the act of forgiveness by reducing the emotional states caused by stress. Athletes may experience significant trauma as a result of staying away from sports after injury. ${ }^{24}$ The length of this stay away can negatively affect the athletes.

In the forgiveness process, Smedes used the metaphor of the journey. For Smedes, forgiveness is a journey with four stations of distancing, forgiveness, reconciliation, and hope. In the process of forgiving, the athlete first moves away from those who caused him to face his negative situation. Then he normalizes the situation and gives up taking revenge. Their relationship returns to normal and they can be freed from the destructive influence of the past. This emotional state can also have a positive effect on the injured athlete's ability to achieve their previous performance. Forgiving initiates reconciliation and the feeling of hope provides the motivating motive and energy to the individual. ${ }^{8}$ In this context, this study aims to contribute to the athletes by examining the effect of forgiveness flexibility as a result of possible sports injuries.

This study aims to examine the relationship between injury anxiety and forgiveness flexibility levels of elite field hockey players. Injury anxiety and forgiveness flexibility levels were compared in terms of gender, the status of being a national athlete status, injury history, and frequency of training. In the literature review, it was seen that the studies on the subject were quite limited and it is thought that this research will contribute significantly to the literature.

\section{METHOD}

In the method section, there are explanations about the model, research group, data collection and analysis processes to be used in the research.

\subsection{Research Model}

In line with the purpose of the research, it is a descriptive research in which the relational survey model, one of the quantitative research methods, is used. With this method, it is used to comprehend and explain the relationship between various variables without any attempt to change the current situation. ${ }^{9}$ In this framework, a research model was created that aims to determine the existence of cochange between two or more variables.

\subsection{Research Group}

Field hockey players constitute the universe of this research. The population of the study consists of elite field hockey players who participated in national or international field hockey tournaments. The research sample consists of 161 participants (66 Female, 41\%; 95\% Male, 59\%) selected by convenience sampling method, which is one of the non-random sampling methods.

\subsection{Data Collection Method}

Due to the difficulties in reaching individuals face-to-face due to the global epidemic, the data were collected from the athletes via the online form (data collection tool) created via Google. First of all, the people to whom the study will be applied were given information about the study. The principle of voluntary participation was taken as a basis in the study and data was started to be collected online. After the collected data were organized, they were transferred to the computer environment for analysis. The "Sports Injury Anxiety" scale was used to determine the injury anxiety levels of field hockey players who participated in the study voluntarily. To determine the levels of forgiveness flexibility, the "Forgiveness Flexibility Scale" and the "Personal Information Form", prepared by the researchers to collect information about demographic characteristics (gender, status of being a national athlete, injury history, training frequency), were used.

Sports Injury Anxiety Scale: It was developed by Rex and Metzler (2016) and its validity and reliability study in our country was carried out by Caz et al., (2019). There are 19 items in total on the scale. Sample items consist of items such as 1 - I lose my sports ability when I get injured, 2- I think I might get injured again when I return to sports after being injured. The scale consists of 6 sub-dimensions. These are; sub-dimensions are "anxiety about losing one's ability", "anxiety about being perceived as weak", "anxiety about suffering", "anxiety about disappointing", "anxiety about losing social support", "anxiety about re-injury". Participants indicated the frequency of exhibiting the behavior indicated by each item on a Likert-type 5-point rating scale. Evaluations were made by giving a score of (5) to the option of strongly agree and (1) to the option of strongly disagree. The Cronbach alpha internal consistency coefficients calculated based on the item analysis of the scale were as .73 for the anxiety of losing ability, anxiety about being perceived as weak.74, anxiety about suffering.79, anxiety about disappointing.86, anxiety about losing social support.84, and .68 for re-injury anxiety.

Forgiveness Flexibility Scale: The scale developed by Çolak (2015) was used.12 The scale consists of 15 items and 3 sub-dimensions. The scale is a five-point Likert type. The scale consists of 3 sub-dimensions: recognition $(1,5,8,12)$, internalization $(2,3,6,7,14)$, and application $(4,9,10,11,13,15)$. Items in the recognition sub-dimension are scored in reverse. Participants indicated the level of forgiveness indicated by each item on a Likert-type 5-point rating scale. Evaluations were carried out by giving a score of (5) to the option I strongly agree with and to the option of I strongly disagree (1). Cronbach's alpha internalconsistency coefficients were calculated as .66 for recognition sub-dimension, .74 for internalization and .69 for practice sub-dimension.

\subsection{Analysis of Data}

Within the scope of the research, the analyzes applied for the data obtained from the "Personal Information Form", the "Sports Injury Anxiety Scale" and the "Forgiveness Flexibility Scale" were carried out using the SPSS 26.0 program. The forms obtained before the analysis of the data were reviewed, and 15 questionnaires that were not filled in accordance with the directive or left blank were excluded from the study. 161 questionnaire forms, which were filled in accordance with the purpose and voluntarily, were evaluated. As a statistical method during the evaluation of the obtained data; Descriptive statistics (standard deviation, frequency, arithmetic mean), whether 
the data meet the requirements of the parametric tests, were decided by looking at the Skewness and Kurtosis values and the Levene test results. When the Skewness and Kurtosis values of the independent variables were examined in the study, it was decided that the parametric tests could be applied because the distribution was between (-1.5) and (+1.5) and was suitable for the normal distribution. T-test, one-way analysis of variance (ANOVA), Tukey HSD multiple comparison test from Post Hoc tests to find the source of differentiation, Pearson Correlation analysis to determine the relationships between variables were used. Simple Linear Regression analysis was used to calculate the predictor. The significance level was accepted as 0.05 in all analyzes.

When Table 1 is examined, it was determined that the scores obtained by the participants from the Injury Anxiety Scale varied between 19 and 71 . Its mean was calculated as $42.07( \pm 11.44)$. The scores obtained from the Forgiveness Flexibility Scale, which is the second measurement tool, also vary between 17 and 71 ; it was determined that the mean was calculated as $45.66( \pm 8.37)$. When the skewness-kurtosis coefficients calculated for the normality assumption of the variables were examined, it was determined that the coefficients took values between 1.5 and +1.5 (injury anxiety: skewness $=.114$; kurtosis $=-$ .500 ; forgiveness flexibility: skewness $=-.707$; kurtosis=1.169). It was found that the variables did not deviate excessively from the normal.

As seen in Table 2, a significant difference was found between the injury anxiety levels of elite field hockey players according to the gender variable ( $t$ value $=2.131$ $p=0.035<.05$ ). While the average of female athletes' injury anxiety levels is ( $\bar{X}=44.35)$, the average of male athletes' injury anxiety levels is $(\bar{X}=40.48)$. Injury anxiety levels of female athletes reveal that the injury anxiety levels of male athletes are higher. According to the gender variable, a significant difference was found between the levels of forgiveness flexibility of elite field hockey players ( $t$ value $=2.462 p=0.015<.05$ ). While the average of female athletes' levels of forgiveness flexibility is $(\bar{X}=47.58)$, the average of male athletes' levels of forgiveness flexibility is $(\bar{X}=44.33)$. It turns out that the forgiveness flexibility levels of female athletes are higher than the forgiveness flexibility levels of male athletes.

As seen in Table 3, a significant difference was found between the injury anxiety levels of elite field hockey players according to the variable of the status of being a national athlete ( $t$ value $=-2.312 p=0.022<.05$ ). The average of injury anxiety levels of non-national athletes is $(\bar{X}=43.77)$, while the average of injury anxiety levels of national athletes is $(\bar{X}=39.52)$. Injury anxiety levels of nonnational athletes reveal that the injury anxiety levels of national athletes are higher. According to the variable of the status of being a national athlete, there is no significant difference between the levels of forgiveness flexibility of elite field hockey players (t value $=-1.879 p=0.062>.05$ ). The average of non-national athletes' forgiveness flexibility levels is $(\bar{X}=46.54)$, while the average of national athletes' forgiveness flexibility levels is $(\bar{X}=44.01)$.

\section{FINDINGS}

Table 1. Findings regarding the kurtosis-skewness, mean, standard deviation and cronbach alpha values of the scores obtained from the measurement tools

\begin{tabular}{|l|l|l|l|l|l|l|l|l|}
\hline & $\mathrm{N}$ & Min. & Max. & Avg. & Std. D. & Skewness & Kurtosis & $\alpha$ \\
\hline Injury Anxiety & 161 & 19 & 71 & 42.07 & 11.44 & .114 & -.500 & .857 \\
\hline Forgiveness Flexibility & 161 & 17 & 71 & 45.66 & 8.37 & -.707 & 1.169 & .725 \\
\hline
\end{tabular}

Table 2. T-test results of injury anxiety and forgiveness flexibility scale scores of elite field hockey players according to gender

\begin{tabular}{|l|l|l|l|l|l|l|l|}
\hline Scale & Gender & $N$ & $\bar{X}$ & $S S$ & $S d$ & $t$ & \\
\hline Injury Anxiety & Female & 66 & 44.35 & 11.32 & 159 & 2.131 \\
\hline & Male & 95 & 40.48 & 11.31 & & & \\
\hline Forgiveness Flexibility & Female & 66 & 47.58 & 5.35 & 159 & 2.462 & $.015^{*}$ \\
\hline & Male & 95 & 44.33 & 9.74 & & & \\
\hline
\end{tabular}

${ }^{\star} \mathrm{p}<0.05 ;{ }^{* *} \mathrm{p}<0.01$

Table 3. T-test results of elite field hockey players' injury anxiety and forgiveness flexibility scale scores according to their status according to status of being a national athletes

\begin{tabular}{|l|l|l|l|l|l|l|l|}
\hline Scale & National Athlete & N & $\bar{X}$ & SS & Sd & $t$ & $p$ \\
\hline Injury Anxiety & Yes & 61 & 39.52 & 9.64 & 158 & $-2,312$ & $.022^{\star}$ \\
\hline & No & 99 & 43.77 & 12.16 & & & \\
\hline Forgiveness Flexibility & Yes & 61 & 44.01 & 9.41 & 158 & -1.879 & .062 \\
\hline & No & 99 & 46.54 & 7.48 & & & \\
\hline
\end{tabular}

${ }^{*} p<0.05 ;{ }^{* *} p<0.01$

Table 4. T-test results of injury anxiety and forgiveness flexibility scale scores of elite field hockey players according to their injury status

\begin{tabular}{|c|c|c|c|c|c|c|c|}
\hline Scale & Injury History & $\mathrm{N}$ & $\bar{X}$ & SS & Sd & $\mathrm{t}$ & p \\
\hline \multirow[t]{2}{*}{ Injury Anxiety } & Yes & 70 & 44.54 & 10.97 & 159 & 2.444 & $.016^{*}$ \\
\hline & No & 91 & 40.16 & 11.48 & & & \\
\hline \multirow[t]{2}{*}{ Forgiveness Flexibility } & Yes & 70 & 46.34 & 8.80 & 159 & .910 & 364 \\
\hline & No & 91 & 45.13 & 8.03 & & & \\
\hline
\end{tabular}

${ }^{*} p<0.05 ;{ }^{* *} p<0.01$ 
The Relationshıp Between Injury Anxiety and Forgiveness Flexıbility: A Research for Elite Field Hockey Athletes

Table 5. ANOVA results of injury anxiety and forgiveness flexibility scale scores of elite field hockey players according to training frequency

\begin{tabular}{|l|l|l|l|l|l|l|l|l|}
\hline Scale & Training Frequency & $\mathrm{N}$ & $\overline{\mathrm{X}}$ & SS & $\mathrm{F}$ & sd & $\mathrm{p}$ & Significant Difference \\
\hline Injury Anxiety & 1-3 Days & 28 & 48.25 & 10.32 & 5.536 & 2 & $.005^{*}$ & $2-3$ \\
\hline & 4-5 Days & 60 & 39.93 & 11.13 & & & & 1 \\
\hline & 6-7 Days & 73 & 41.52 & 11.40 & & & 1 \\
\hline Forgiveness Flexibility & 1-3 Days & 28 & 48.28 & 5.28 & 3.768 & 2 & $.025^{*}$ & 2 \\
& 4-5 Days & 60 & 43.51 & 9.60 & & & & \multirow{2}{*}{1} \\
& 6-7 Days & 73 & 46.41 & 7.91 & & & & \\
\end{tabular}

${ }^{*} p<0.05 ;{ }^{* *} p<0.01$

Table 6. Pearson correlation coefficient findings on the relationship between injury anxiety and forgiveness flexibility in elite field hockey players

\begin{tabular}{|c|c|c|c|}
\hline \multicolumn{2}{|l|}{$\mathrm{N}=161$} & \multirow{2}{*}{\begin{tabular}{|l|}
1.000 \\
\end{tabular}} & 2 \\
\hline Injury Anxiety & $r$ & & \\
\hline \multirow[t]{2}{*}{ Forgiveness Flexibility } & r & $282^{\star \star}$ & 1.000 \\
\hline & $\mathrm{p}$ & .000 & \\
\hline Average & & 42.07 & 45.66 \\
\hline Standard Deviation & & 11.44 & 8.37 \\
\hline
\end{tabular}

${ }^{*} p<0.05 ;{ }^{* *} p<0.01$

In Table 6, it was determined that there was a statistically significant correlation between injury anxiety and total score and forgiveness flexibility at a low level $(r=.282 ; p<0.05)$.

Table 7. Simple linear regression analysis results on the prediction of injury anxieties of elite field hockey players

\begin{tabular}{|l|l|l|l|l|l|}
\hline Variable & B & Standard Error & Beta & $t$ & $\mathrm{t}$ \\
\hline Stable & 47.690 & 2.887 & & 16.517 \\
\hline Injury Anxiety & -2.466 & 1.205 & -.160 & -2.047 \\
\hline $\mathrm{R}=.-160 \mathrm{R}^{2=} 0.26 \mathrm{p}=.042$ & & & & .000 \\
\hline
\end{tabular}

${ }^{*} \mathrm{p}<0.05 ;{ }^{* *} \mathrm{p}<0.01$

As seen in Table 4, a significant difference was found between the injury anxiety levels of elite field hockey players according to the variable of injury status ( $t$ value $=-$ $2.444 p=0.016<.05)$. While the average of the injury anxiety levels of the athletes with a history of injury is $(\bar{X}=44.54)$, the average of the injury anxiety levels of the athletes without a history of injury is $(\bar{X}=40.16)$. Injury anxiety levels of athletes with a history of injury reveal that the level of injury anxiety of athletes without a history of injury is higher. According to the variable of injury status, there is no significant difference between the levels of forgiveness flexibility of elite field hockey players (t value $=.910$ $p=0.364>.05)$. The average of the forgiveness resilience levels of the athletes with a history of injury is $(\bar{X}=46.34)$, while the average of the forgiveness resilience levels of the athletes without a history of injury is ( $\bar{X}=45.13)$.

The results of the analysis show that there is a significant difference between the injury anxiety levels of the elite field hockey players according to the training frequency, $F=5.536, p<0.05$. The injury anxiety levels of the athletes vary significantly depending on the training frequency. Tukey HSD test was used to find out between which groups the differences were among units, since the variances were equal and it was a powerful test. According to the results, it was determined that there are significant differences between the athletes who train 1-3 days a week and the athletes who train for 4-5 and 6-7 days. It was determined that the athletes who trained for 1-3 days $(\bar{X}=48.25)$ had the highest injury anxiety levels. It shows that there is a significant difference between the levels of forgiveness flexibility of elite field hockey players according to training frequency, $F=3.768, p<0.05$. Forgiveness flexibility levels of athletes vary significantly depending on the training frequency. Tukey HSD test was used to find out between which groups the differences were among units. According to the results, it has been determined that there are significant differences between the athletes who train 13 days a week and the athletes who train for 4-5 days. It was determined that the athletes who trained for 1-3 days $(\bar{X}=48.28)$ had the highest levels of forgiveness flexibility.

As a result of the analysis made in Table 7, it is stated in the model established that the variable of training frequency is a statistically significant interpreter of injury anxiety $(R=0.160, R 2=0.26, F=4.192, p<0.05$. In other words, the frequency of training $(\beta=.-160, p<0.05)$ was found to have a statistically significant contribution.

\section{DISCUSSION RESULT}

This study was carried out to determine the relationship between injury anxiety and forgiveness flexibility levels of elite field hockey players. The research was designed considering the personal characteristics of field hockey players. It is aimed to discuss the results of the athletes' injury anxiety and forgiveness flexibility levels and the relationships between dependent variables, taking into account the gender, nationality, injury history, and training frequency in the personal information form created by the researcher.

When the t-test results of the injury anxiety and forgiveness flexibility scale scores of elite field hockey players by gender were examined; it was found that a significant difference was found in the mean scores of injury anxiety and forgiveness flexibility $(p<0.05)$. According to this result, it was concluded that the mean scores of 
women's injury anxiety and forgiveness flexibility were higher than men's. In other words, both injury anxiety and forgiveness flexibility scores of women are higher. Regarding the result, the reason why women have higher injury anxiety scores can be shown as the fact that female athletes attach importance to their physical appearance in order to meet their social needs, and in this respect, they can act more cautiously in order to prevent the damage that may occur in their physical appearance due to injury. For this reason, the mean score of women's injury anxiety may be higher than that of male athletes. Regarding the result, Tanyeri (2019) concluded in his study that there are significant differences between the gender variable and injury anxiety. ${ }^{13}$ Tanyeri's study showed that men are physically stronger than women, leading to significant results in favor of male athletes. According to this result, the mean score of injury of women is higher than that of men. Yalçınkaya et al. (2020), on the other hand, found in their study that there was a significant difference between the genders in favor of female participants in the anxiety about suffering sub-dimension between male and female participants, while there was no significant difference in other sub-dimensions. Looking at similar studies, Correia and Rasoda (2019) examined the sports branch in their study and concluded that female athletes have higher anxiety levels. ${ }^{15}$ Şahin and Türksoy (2017) examined the psychological resilience of football players who had an anterior cruciate ligament injury in their study and concluded that stress-related injuries are an important cause of injury in both males and female athletes. ${ }^{27}$

It can be said that the reason why women's average scores of forgiveness flexibility are higher than men's is that women internalize traditions by kneading them in themselves, due to their social roles. Similar to the result, Kara (2020) concluded in her study that women's mean scores in the internalization sub-dimension, which is the forgiveness flexibility sub-dimension, are higher than that of men. ${ }^{16}$ In another study; Batum and Öktem (2011) examined the effect of diagnosis and gender on problems in their study and found that the common effect of gender was significant. ${ }^{17}$

When the t-test results of the elite field hockey players' injury anxiety and forgiveness flexibility scale scores were examined according to their status as national athletes; a significant difference was found in the mean score of injury anxiety levels of elite field hockey players $(p<.05)$. In other words, it was concluded that the injury anxiety levels of the non-national athletes were higher than the injury anxiety levels of the national athletes. Regarding the result, the fact that the national athletes have reached the national jersey and that they have proven themselves can provide self-confidence to the national athletes and make them more assertive and courageous. On the other hand, the reason for the high score averages of field hockey players, who are not national athletes, may cause them to avoid injury more because of their desire to wear the national jersey. Considering similar studies; Bayındır (2021) concluded that there is no significant difference between the success of the athletes and their anxiety levels for a sports injury. ${ }^{18} \mathrm{He}$ stated that the reason why there was no significant difference between them was that all of the wrestlers were successful at the national level and they were national athletes.

Considering the t-test results of the forgiveness flexibility scale scores of elite field hockey players according to their injury status; A significant difference was found in the mean scores of injury anxiety $(p<0.05)$. According to this result, the mean score of injury anxiety of those with a history of injury is higher than the mean score of those without a history of injury. The reason for the result can be given as an example for those who have an injury history to avoid themselves more in order not to experience the same situation again due to the difficult situations they have experienced. However, in the study of Tanyeri (2019), when the difference between the athletes' experience of any surgery on the legs or arms and the anxiety of sports injury was examined, no difference was found between the sports that had undergone any surgery on the legs or arms before and those who did not. ${ }^{13}$ When the literature was searched, there was no study examining the flexibility of forgiveness according to the variable of having an injury.

When the ANOVA results of the elite field hockey players' injury anxiety and forgiveness flexibility scale scores were examined according to the training frequency, it was determined that there was a significant difference $(p<0.05)$. According to the results, it was determined that there were significant differences between the athletes training 1-3 days a week and the athletes training 4-5 and 6-7 days. It was determined that the athletes who trained for 1-3 days had the highest injury anxiety levels. As the reason for this situation, it can be given as an example that as the weekly training frequency decreases, there may be a decrease in the endurance level, and injury anxiety may increase. Looking at the literature, Arıkan and Çimen (2020) concluded in their study that, in terms of the number of training days per week, those who do physical training 1 2 days a week and those who train 3-4 days or more have higher "Anxiety about Losing Ability" scores. ${ }^{19}$

Forgiveness flexibility levels of athletes vary significantly depending on the training frequency $(p<0.05)$. It has been determined that the athletes who train 1-3 days a week have the highest levels of forgiveness flexibility. Looking at the result; As the number of weekly training increases, the desire of the athletes to achieve increases, the athletes become more ambitious, and this may lead the athletes to have less forgiveness flexibility. Looking at similar studies, Kara et al. (2021) found that there was no significant difference in forgiveness flexibility scores according to the year of doing sports in the study conducted by Kara et al. (2021). ${ }^{20}$

The Pearson Correlation Coefficient was calculated to determine the relationships between injury anxiety and forgiveness flexibility of elite field hockey players participating in the study. According to the results; A positive and significant relationship was found between the total scores of injury anxiety and the total scores of forgiveness flexibility $(p<0.05)$. In other words, it was concluded that as the injury anxiety increased, the level of forgiveness flexibility of the athlete increased. Athletes may take more forgiving actions as they avoid injury. The reason for this situation can be given as an example to the thought that if the athletes do not forgive the opponent who caused the injury, the opponent will continue his 
aggression. No similar study has been found with this result in the literature.

Considering the results of the analysis regarding the prediction of injury concerns of elite field hockey players; the training frequency variable was found to be a significant predictor of injury anxiety $(p<0.05)$. A negative and significant relationship was found between the total scores of injury anxiety and the frequency of training $(p<0.05)$. In other words, it was concluded that as the training frequency increased, the injury anxiety level of the athlete decreased. That is, training frequency is an important determinant of injury anxiety. Regarding the result, although injury anxiety is a concept that occurs in the mind of the athlete, it can be said that the biggest factor in the formation of this concept is the effects of the injuries caused by physical training on the athletes and training planning. In addition, the success and injuries of athletes are undoubtedly closely related to the frequency of training. Ertan et al. (2005) investigated the causes of injuries suffered by athletes and stated that $28.4 \%$ of them were caused by overloading. ${ }^{21}$ As a result of the research, it was determined that there was a significant difference in injury anxiety and forgiveness flexibility scores of elite field hockey players according to gender and training frequency variables. On the other hand, there was a significant difference in injury anxiety scores according to the status of being a national athlete and having an injury, but no significant difference was found in the mean scores of forgiveness flexibility. As a result of the analysis performed to determine the relationship between injury anxiety and forgiveness flexibility, a positive and significant relationship was determined between the injury anxiety and forgiveness flexibility levels of the athletes. Finally, it was understood that training frequency was an important predictor of injury anxiety, and it was concluded that as the training frequency increased, the athlete's injury anxiety level decreased. In their study, Olsen et al. concluded that functional capacity, physical activity level, and shoulder functions decreased in individuals who underwent surgery after rib fractures. ${ }^{22}$ In addition to their efforts to get rid of the anxieties experienced by the athletes due to their injury, they also consider the possibility of injury again. ${ }^{23}$ Taş et al., in their study on fear of movement and musculoskeletal injuries, emphasized that there is a negative relationship between fear of movement and catastrophic thought, physical disability, and quality of life in individuals with lower and upper extremity injuries. 28 In another study, Çiçek, M. E. (2019) concluded that the high rate of injury in football players with a history of injury is due to psychological and similar reasons. ${ }^{29}$ The warm-up time of the athletes is also one of the important points in terms of injury. Looking at the studies in the literature on warm-up times, there are studies that examine the injury status of football players according to their warm-up times. Again, in his study, Çiçek concluded that the warm-up period did not affect the occurrence of injury. In the literature, besides the studies stating that warming up before physical activity reduces the risk of injury, there are also studies reporting that warming up has no effect on injury. ${ }^{30-31}$

\section{LIMITATIONS AND RECOMMENDATIONS}

As in other studies, this study also has limitations arising from the process and scope, as well as methodological limitations, and suggestions for future research. This research was carried out with convenience sampling method, which is one of the non-random sampling methods, so more generalizable results can be obtained from the researches planned with the probability sampling method. Within the scope of the research, only field hockey players who participated in national or international competitions were reached. Different results can be obtained from research that will be carried out by reaching field hockey players in different countries.

Conflict of Interest: The authors declare that the research was conducted in the absence of any commercial or financial relationships that could be construed as a potential conflict of interest.

\section{REFERENCES}

1. Timpka, T., Jacobsson, J., Bickenbach, J., Finch, C. F., Ekberg, J., \& Nordenfelt, L. (2014). What is a sports injury?. Sports medicine, 44(4), 423-428.

2. Ivarsson, A., \& Johnson, U. (2010). Psychological factors as predictors of injuries among senior soccer players. A prospective study. Journal of sports science \& medicine, 9(2), 347.

3. Maddison, R., \& Prapavessis, H. (2005). A psychological approach to the prediction and prevention of athletic injury. Journal of Sport and Exercise Psychology, 27(3), 289310. Organizational Behaviour. Journal of Organizational Behavior Management, 26, 25-54.

4. Enright, R. D. (1996). Counseling within the forgiveness triad: On forgiving, receiving forgiveness, and selfforgiveness. Counseling and values, 40(2), 107-126.

5. Gordon-Salant, S., \& Fitzgibbons, P. J. (2004). Effects of stimulus and noise rate variability on speech perception by younger and older adults. The Journal of the Acoustical Society of America, 115(4), 1808-1817.

6. Bond, F. W., Hayes, S. C., \& Barnes-Holmes, D. (2006). Psychological flexibility, ACT, and organizational behavior. Journal of Organizational Behavior Management, 26(1-2), 25-54.

7. Çolak, T. S. (2014). Logoterapi Yönelimli Grupla Psikolojik Danışmanın Affetme Esnekliği Kazandırma Üzerindeki Etkisi. Yayınlanmamış doktora tezi. Sakarya Üniversitesi, Sakarya

8. Ayten, A. (2009). Affedicilik ve Din: Affetme Eğilimi ve Dindarlıkla İlişkisi Üzerine Ampirik Bir Araştırma. Marmara Üniversitesi Illahiyat Fakültesi Dergisi, (37), 111-128.

9. Büyüköztürk, Ş., Çakmak, E. K., Akgün, Ö. E., Karadeniz, Ş., Demirel, F. (2009). Bilimsel araştırma yöntemleri. 3. Baskı Ankara: Pegem Akademi. International Journal of Psychological Research, 12(1), 9-17.

10. Rex CC, Metzler JN. (2016). Development of the sport injury anxiety scale. Meas Phys Educ Exerc Sci.;20(3): 146- 58.

11. Caz, Ç., Kayhan, R. F., \& Bardakçı, S. (2019). Spor Yaralanması Kaygı Ölçeği'nin Türkçeye Uyarlanması: Geçerlik ve Güvenirlik Çalışması. Spor Hekimligi Dergisi/Turkish Journal of Sports Medicine, 54(1).

12. Çolak, T. S., Koç, M., Eker, H., \& Düşünceli, B. (2017). Forgiveness Flexibility Scale For Secondary Education: Validity and reliability study Ortaöğretim Öğrencilerinde Affetme Esnekliği Ölçeği: Geçerlik ve güvenirlik çalıG̦ması. Journal of Human Sciences, 14(1), 63-73.

13. Tanyeri, L. (2019). Farklı branş sporcularında yaralanma kaygısının incelenmesi. OPUS Uluslararası Toplum Araștırmaları Dergisi, 13(19), 577-591.

14. Yalçınkaya, A., Demirci, M., ve Kızılyar, N.G. (2020). Beden Eğitimi ve Spor Yüksekokulu Öğrencilerinin Spor Yaralanmalarında ki Kaygı Düzeylerinin İncelenmesi. Uluslararası Bozok Spor Bilimleri Dergisi, 1(1), 43-51. 
15. Correia, M., ve Rosado, A. (2019). Anxiety in athletes: gender and type of sport differences.

16. Kara N, Ş (2020). Spor yapan ve yapmayan bireylerde yaşamın anlamı, affetme esnekliği, bilişsel esneklik ile psikolojik belirtilerin çeşitli değişkenler açısından incelenmesi.(Yayımlanmış Doktora Tezi). Sakarya Uygulamalı Bilimler Üniversitesi, Lisansüstü Eğitim Enstitüsü, Sakarya.

17. Batum, P., \& Öktem, F. (2011). Öğrenme bozukluklarında ebeveyn kabulü/reddi ile içselleştirme ve dışsallaştırma sorunlarının incelenmesi. Çocuk ve Gençlik Ruh Sağlığı Dergisi

18. Bayındır O. (2021).Elit genç güreşçilerin spor yaralanması kaygı düzeylerinin incelenmesi. (Yayımlanmış Yüksek Lisans Tezi). Hitit Üniversitesi, Lisansüstü Eğitim Enstitüsü, Çorum.

19. Arıkan, G., \& Çimen, E. (2020). Üniversite Adaylarının Spor Yaralanma Kaygı Düzeylerinin İncelenmesi. Eurasian Research in Sport Science, 5(2), 118-127.

20. Kara, N. S., \& Soyer, F. (2021). Examination of Meaning in Life, Forgiveness Flexibility, Cognitive Flexibility, and Psychological Symptoms in Individuals Doing Sports and Not Doing Sports in Terms of Various Variables. African Educational Research Journal, 9(1), 146-159.

21. Ertan, H., Kentel, B. B., Tümer, S. T., \& Korkusuz, F. (2005). Reliability and validity testing of an archery chronometer. Journal of sports science \& medicine, 4(2), 95.

22. Turhan, B., Usgu, G., Usgu, S., Çınar, M. A., Dinler, E., \& Kocamaz, D. (2019). Alt Ekstremitede Bağ Yaralanması veya Kırık Geçmişi Olan Bireylerde Kinezyofobi, Durumluluk ve Sürekli Kaygı Düzeylerinin İncelenmesi. Spor Hekimliği Dergisi, 54(3), 175-182.

23. AKSOY, D. (2019). Spor yaralanmalarinda tedavi sonrasi durumluk ve sürekli kaygi düzeylerinin incelenmesi. Beden Eğitimi ve Spor Bilimleri Dergisi, 21(2), 89-96.
24. Mankad, A. Gordon, S. \& Wallman, K., (2009), Perceptions of Emotional Climate Among Injured Athletes, Journal of Clinical Sport Psychology, 3, 1- 14.

25. Petitpas, A. \& Danish, S. J., In S. M. Murphy (Ed.), (1995), Caring for Injured Athletes. Sport Psychology Interventions (s. 253- 306). Champain III: Human Kinetics.

26. Bulut, Z., \& Kılıçaslan, Ç. (2009). Çocuğa özgüven kazandırmada önemli bir ilke; çocuk oyun alanlarında güvenlik.

27. TÜRKSOY, A. ÖN CAPRAZ BAĞ YARALANMASI GEÇǴREN FUTBOLCULARIN PSǴKOLOJǴK SAGLAMLIKLARININ ǴNCELEMESǴ ÜZERǴNE NǴTEL BǴR ARAg்TIRMA3 Özet.

28. TAŞ, S., ŞAHAN, N., \& YILMAZ, Ö. T. (2020). Üst ve Alt Ekstremite Kas-İskelet Sistemi Yaralanmalarında Hareket Korkusu, Psikolojik Faktörler ve Yaşam Kalitesinin Karşılaştırılması. Turkiye Klinikleri Spor Bilimleri, 12(2)

29. Ciçek, M. E. (2019). Futbolcularda Görülen Spor Sakatlıklarının Bireysel Faktörler Açısından Değerlendirilmesi (Master's thesis, ERZINCAN BINALI YILDIRIM ÜNIVERSITESI SAĞLIK BÍLIMLERI ENSTITÜSÜ).

30. Wedderkopp, N., Kaltoft, M., Lundgaard, B., Rosendahl, M. and Froberg, K. (1999). Prevention of injuries in young female players in European team handball. A prospective intervention study. Scandinavian Journal of Medicine and Science in Sports, 9(1), 41-7.

31. Van Mechelen, W., Hlobil, H., Kemper, H. C., Voorn, W. J. and de Jongh, H. R. (1993). Prevention of running injuries by warm-up, cool-down, and stretching exercises. The American Journal of Sports Medicine, 21(5), 711-19. 